\title{
Discurso de recepción de Medalla Rectoral de la profesora María Teresa Infante Caffi
}

Recibo esta Medalla Rectoral como un honor inmerecido. Leo que ella se concede a miembros de la comunidad universitaria que han realizado acciones y servicios en favor de la Universidad, que han mostrado una especial capacidad y dedicación o se han destacado en acrecentar el prestigio de la Universidad a nivel nacional o internacional. Es tal vez una señal de que todavía hay camino que recorrer, y que debo tratar de no equivocar la ruta.

$\mathrm{Al}$ imaginar esta ceremonia, recordé que en esta misma Casa Central me correspondió decir unas palabras para honrar a la primera persona distinguida con esta Medalla, la entonces Presidenta de Irlanda, Mary Robinson. Al encontrarme en la extraña posición de ser yo quien recibiría esta distinción, no encontraba los términos para expresar con la debida coherencia el agradecimiento hacia la Universidad, su Rector y a la directora del Instituto de Estudios Internacionales, por sumar mi nombre al de Alberto van Klaveren, en este acto.

He vivido la Universidad de Chile como un descubrimiento desde que entré a sus aulas, y a partir de ese momento, han transcurrido etapas importantes de formación y aprendizaje. Nuestras formas de debatir, de apreciar decisiones públicas, de compartir progresos, conflictos y encuentros, las negociaciones internas, elecciones y proyectos, y sobre todo integrar pequeñas comunidades que significan formas de vida en el seno de la particular institucionalidad universitaria. Todo ello ha sido parte del tiempo transcurrido.

La Universidad ha sido siempre exigente, lo son los estudiantes, las formas de gobierno, la necesidad de ejercer la tolerancia, y la urgencia de producir, a la espera de una próxima calificación. Desde este universo, se vive y se debate sobre preocupaciones nacionales, y junto con la libertad, la calidad, y el pluralismo, características a las que no renuncio, en la universidad he podido disfrutar del uso del razonamiento, del mérito, de las emociones, y, a veces, hasta de desilusiones propias del entorno universitario y humano.

En este espacio, el derecho internacional ha sido y es un eje importante para situar perspectivas claves de la realidad internacional y nacional. Así se ve, actualmente, en los difíciles procesos de paz de conflictos internos; en la búsqueda de la eficacia de los regímenes sobre armas de destrucción masiva; en las 
dificultades que enfrenta el sistema del comercio internacional; los cambios propuestos a la solución de controversias entre estados y otras entidades; las dimensiones globales y específicas de la protección del medio ambiente; los recursos pesqueros; la cooperación interestatal en materias jurídicas; la lucha contra la impunidad ante crímenes graves, y las cuestiones que suscitan para la jurisdicción de los estados, entre otros temas. ¿Dónde tenemos que situarnos? ¿qué aportamos? ¿qué esperamos? ¿tenemos socios para avanzar ideas y ampliar los consensos? Son las preguntas que me he hecho al abordar los temas nuevos.

Esta visión no surge de un vacío. El derecho internacional ocupó un lugar en los grandes ejercicios diplomáticos del siglo xx, a nivel regional y mundial, y vale la pena examinar lo que se escribía en diversas épocas del siglo pasado, y cómo nuestro país consideraba su participación en esos procesos.

Lejos de estimar el derecho como una esfera ajena a decisiones estratégicas, y desapegado de preocupaciones reales; al contrario, el derecho se entendía como un vehículo para dar efectividad a intereses especiales y garantizar formas de conducta aceptadas por diversos estados, después de períodos de incertidumbre y como formas de superar controversias y conflictos.

Pensemos en las largas discusiones sobre las 200 millas de soberanía y jurisdicción, en los debates del entonces llamado nuevo derecho del mar, en la larga generación de los pactos generales de derechos humanos, y en la acuciante necesidad actual de fortalecer una cultura jurídica de la responsabilidad, que es una de las tareas de nuestro tiempo. A veces quisimos saltar etapas y asumir posiciones de ruptura, reconociendo después que pudo adoptarse otra perspectiva menos costosa.

Quiero decir que la experiencia vivida por nuestro país al enfrentar distintos casos ante la Corte Internacional de Justicia con países vecinos, junto a otras controversias que fueron sometidas al arbitraje internacional, y que han tenido fuertes componentes territoriales, no pueden entenderse sin comprender la integridad de las relaciones internacionales y de qué manera el lenguaje y las definiciones con alcance jurídico pudieron ser relevantes o decisivas para sostener la defensa de nuestro país.

Los tiempos políticos a veces dificultan la apreciación de este fenómeno, pero no se puede renunciar a reflexionar y marcar la diferencia que presta una asesoría o plantear un punto de vista en un proceso que puede llegar a impactar en la vida de un país o de una región. Pienso en al menos dos temas que pude apreciar desde el trabajo de la Cancillería, donde la sensibilidad jurídica pudo asociarse adecuadamente en la generación de acuerdos: el Acta de Ejecución de algunas disposiciones pactadas con el Perú en 1929, y que se celebrara en I999, su reglamento e instrumentos complementarios, y la mirada permanente sobre temas atinentes al libre tránsito convenido con Bolivia, en circunstancias 
que requerían sintonizar a actores internos, públicos y privados, peticiones y marcos normativos, respetando el marco jurídico internacional. Distintos temas, sensibilidades similares. No siempre es posible alcanzar la necesaria cercanía, aunque no debemos renunciar a buscarla.

Por estas razones, creo que la universidad constituye una base fundamental para el despliegue de capacidades que apoyan el discernimiento capaz de distinguir entre los elementos y factores que caracterizan las relaciones internacionales, que no desprecia las formalidades y el contenido del derecho y que avanza más allá, conociendo la práctica internacional, la aplicación de los tratados internacionales y sus mecanismos de supervisión, y la labor de los tribunales internacionales, entre otros.

Concluyo afirmando que la Universidad continúa siendo una fuente de inspiración en las labores que realizo en el Ministerio de Relaciones Exteriores, ahora como Embajadora ante los Países Bajos. Y por cierto, el apoyo de las autoridades del Ministerio, desde que iniciara una colaboración permanente cuando era ministro José Miguel Insulza, hasta la fecha, donde he podido trabajar con valiosos ministros y ministras, junto a subsecretarios y subsecretarias, apreciando sus capacidades de reflexión y distintas preferencias y estilos. A ellos sumo la relación dialogada con los agentes que Chile ha designado para actuar en $\mathrm{La}$ Haya, y la renovación de las confianzas que ha significado trabajar junto a ellos.

Son años que han entregado insustituibles conocimientos, valoraciones personales, aprendizajes sobre culturas jurídicas, afectos y preguntas que dejan imágenes y huellas que no se borran. La lealtad que merecen las personas con las que he andado esta ruta, constituye un norte en mi vida actual, lejos del país.

La vocación académica se despliega en medio de incertidumbres. Así es también la realidad internacional. En ese ámbito, la confianza, la excelencia y el respeto a las personas, sin distinciones de rango, ocupan siempre el primer lugar y la Universidad tiene allí un rol principal.

Gracias por esta Medalla que me ha obligado a reflexionar ante ustedes. Gracias además por compartirla con el profesor Alberto van Klaveren, cuya trayectoria cumple con los méritos exigidos por la Medalla Rectoral y es ejemplo de servicio y valor. 
